\title{
BIODIVERSITY CONSERVATION: WHY LOCAL INHABITANTS DESTROY HABITAT IN PROTECTED AREAS
}

\author{
${ }^{*} \mid K P A, T . F^{1} .$, DERA, B. A2 \& JANDE, J. A3.
}

1Department of Wildlife and Range Management, University of Agriculture, P.M.B. 2373 Post Code 970001 Makurdi, Nigeria.

2Department of Forest Production and Products, University of Agriculture P.M.B. 2373 Makurdi, Nigeria.

${ }^{3}$ Department of Social and Environmental Forestry University of Agriculture P.M.B. 2373 Makurdi, Nigeria.

*terwasefsi@yahoo.com.

\section{ABSTRACT}

This review identifies some intrinsic and extrinsic factors that tend to drive the destruction of habitat, game poaching and unsustainable utilization of plants products by communities surrounding many protected areas around the world, leading to wildlife and plant species decline. Intrinsic factors are basic needs of the locals; those needs are intricately tied to land and poverty. Other factors also exist such as increased population, trade in endangered species and deforestation that are extrinsic and not the immediate needs of the local communities in protected areas but nevertheless contribute in forcing the communities to abandon the path to sustainable utilization of natural resources in protected areas leading to habitat fragmentation, depletion and loss of wildlife and plants species

Key words: Protected areas, wildlife, habitat, biodiversity, conservation

\section{INTRODUCTION}

The establishment of protected areas as sites for the conservation of biodiversity in many parts of world was meant to reduce the damaging impact of human activities on natural habitat in order to maintain the balance needed for the conservation of plants and wildlife for sustainable utilization (Eken et al., 2004). However, destructive utilization of wildlife and plants products has become a common feature of protected areas. Several studies have revealed serious problems between the management and the immediate communities in most protected areas of the world that continue to make human interference in these areas unavoidable (Mbaiwa 2005, Ancrenaz et al., 2007, Garcia-Frapolli et al., 2009). In spite of genuine efforts in some cases to recruit members of the host community as stakeholder to participate in the biodiversity conservation scheme, some members of these communities view the establishment of protected areas as insensitive to their needs (Wilshusen et al., 2002, Berkes 2004), since the rights to most of their lands is not retained.
Even though the local communities do enter into agreements with park authorities to promote biodiversity conservation by sustainable utilization of available natural resources in the protected areas, they usually renege on these agreements as they actively collaborate and participate in habitat destruction, game poaching, illegal tree logging and unsustainable exploitation of other forest products (Wood, 1993). This review is aimed at elucidating the factors that promote anti conservation practices among the local people in protected areas, and to proffer useful solutions to curbing these practices.

\section{PROTECTED AREAS}

These are areas formed by an extant legislation for the purpose of conservation of biodiversity by national and international conservation agencies (Sekhar, 2003). They include national parks, games reserves, forest reserves, wildlife sanctuaries, and wilderness areas. Many species of plants and wildlife have been threatened to extinction as a result of human activities and changing environmental or climatic conditions. The establishment of protected areas create suitable environment for different species to thrive under natural or management conditions (Rodrigues et al., 2004). These areas are meant to be free from exploitation pressures that are exerted on biodiversity resources and other forms of non renewable natural resources (Hogkins et al., 2006). Because these areas take up a large chunk of useable land from the indigenous people, denying them ownership rights, and resources exploitation which they had hitherto enjoyed in the past (Dikobe 1995, Mbaiwa, 2005), many local communities in protected areas resists such land "usurpation." This antagonism to protected areas by the local people can be traced to several identified factors (Chambers, 1986; Dikobe, 1995; Ferraro, 2002; Gillingham \& Lee, 2003; Shanley and Luz, 2003; Wittemyer et al., 2008; Mundia \& Murayama 2009). The reasons may vary from one protected area to another (Fig 1). The bottom line however is that many designated protected areas are merely "paper parks" (Carey et al., 2000, Garcia-Frapolli et al., 2009). They are not really protected from human interference particularly from the local communities that adjoin the area in question (O'Riordan, 2002). The over exploitation of flora or fauna and other natural resources within these areas destroy the natural habitat, which become unsuitable for the growth of many flora species on which wildlife species depend upon for food and cover from predators. Consequently, both wildlife and important plant species continue to decline. The major factors that have been identified as contributing to these activities that militate against biodiversity conservation objectives in protected areas are shown in Fig. 1. 


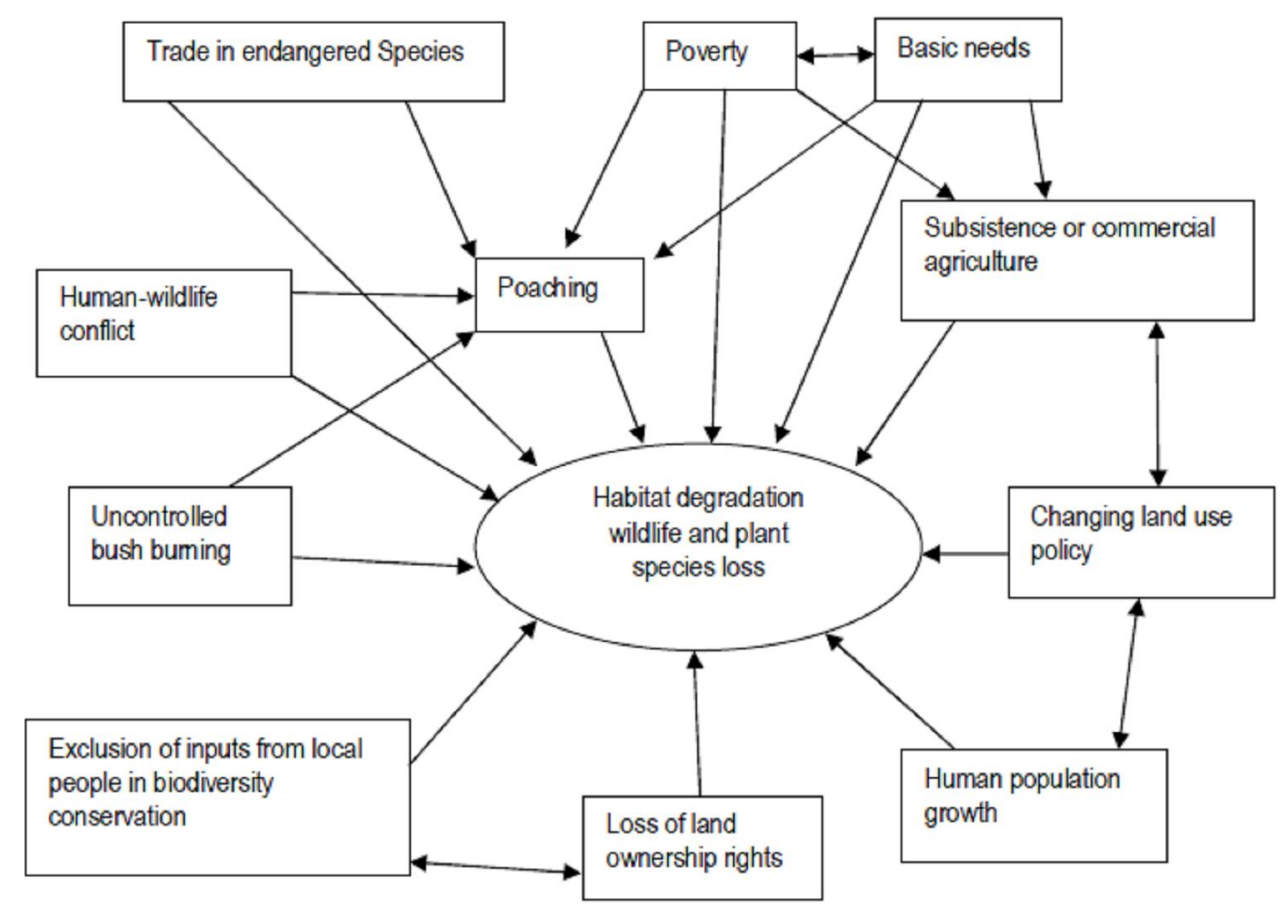

\section{FIG. 1. MAIN FACTORS THAT CAUSE HABITAT DEGRADATION BY COMMUNITIES IN PROTECTED AREAS}

The question is how are these factors directly or indirectly linked to habitat destruction and the decline in wildlife and plants species in these protected areas? In an attempt to answer, we link these factors with the primary (or basic internal needs) and secondary (or external needs or pressures) felt by the local human population around protected areas.

\section{EXPLOITATION OF PROTECTED AREAS}

As important as the need to conserve biodiversity is to the conservation community all over the world, local communities that reside in the protected areas also depend on the available resources for their basic needs (Borrini-Feyerabend et al., 2004) and form the fulcrum upon which the urge for sustainable or unsustainable exploitation of protected areas revolves. Both basic needs and poverty are interwoven as key factors that lead to biodiversity resources over exploitation and habitat degradation in protected areas (Chambers, 1986). Because there may not be alternatives to the communities' basic needs outside the protected areas, and even if these alternatives do exist, the level of poverty may hinder the procurement of these needs, the local people would have to fall back on obtaining their needs from these protected areas. Land cultivation for subsistence agriculture in the protected area belongs to this category (Mundia \& Murayama, 2009). However, what may constitute a collection of basic needs of communities in protected areas may differ geographically from place to place, based on the culture or environmental conditions of the given area (Dikobe, 1995). It is therefore the responsibility of authorities concerned with the responsibility of managing these areas to identify the immediate and specific basic needs of the people and provide for them. This would ease off the unauthorised exploitation pressures that would otherwise be exerted on the protected area in question. We refer to these basic local communities needs as intrinsic factors.

Intrinsic Factors That Are Linked to Basic Needs and Poverty of the Local Inhabitants: The intrinsic factors are internal pressures or primary forces that push the immediate communities where protected areas are located to trespass and poach resources within these areas. These forces can be viewed as just the basic requirements which can be obtained from the protected areas that are needed by the poor members of the community for their daily survival or well being but can not be obtained elsewhere. Therefore, except alternative sources of similar resources are provided free of charge for utilization by these communities, the local population would not be deterred from trespassing on the protected areas, no matter the existing legislation, or punitive measures that would be put in place (Ferraro, 2002). Some of the most common needs in poverty stricken communities include the following:

\section{Energy/fuel requirements}

Energy is needed to do work and can be obtained from food. Fuel is required to prepare food, and in most rural communities without access to electricity or cooking gas, fuel can be readily found in the form of fuel wood just nearby in the protected area. In Africa, the exploitation of fuel wood results to the killing of trees and the destruction of the general vegetation (Ribot 1993, Tabuti et al., 2003). Some food items are found in the wild and are collected and eaten by the locals (Harris \& Mohammed 2003). Viewed in this context, it can be argued that energy needs derived from food or 
fuel to cook could compel the local people to trespass and poach food items that are found naturally in the protected areas. For instance, the unauthorized search for and gathering of truffles as well as fruits from the forests that are protected may be mainly to get food and increased nutritional values for the local inhabitants around the protected area (Kiwasila \& Homewood 1999). However this would just be for survival particularly in difficult periods preceding harvest period of staple food in poor rural communities when food is scarce to sustain families (Ogle, 1996).

Similarly, the unauthorized collection of fire wood or killing of forest trees in reserved areas to create charcoal as fuel for homestead consumption could be linked with the same desire to satisfy a basic need, since the heat energy generated from the burning of the fuel wood would be used to cook food for the immediate family. These actions may lead to gradual alteration and destruction of the forest habitat by the activities of the local inhabitants; however, they would be driven solely by the desire to satisfy basic food and fuel requirements.

\section{Land transformation for food production}

This factor is also linked to the immediate needs of the community in addressing their basic food needs. Food is needed for survival, but land has to be cultivated to produce same. Land cultivation increases the prospect of soil erosion, and disturbs the biodiversity equilibrium of the floral upon which most of the fauna species of the protected areas depend. Cultivation of the land involves bush clearing; in the end it may provide food for the local human population but may at the same time deplete food available to wildlife species in the area causing them to migrate in search of better food sources (Mundia \& Murayama, 2009).

Communities living around protected areas, often encroach upon these areas, transforming them into agricultural lands for subsistence farming (Wessels et al., 2003), and the rearing of live stock which are dear to them as the wildlife is important to conservationist (Mundia \& Murayama, 2009). Some times the compensation promised by the constituted authorities during the acquisition of such land for the establishment of the protected areas is often not paid, thus the local inhabitants still lay defacto claim to the land as their legitimate possession and continue to exploit, and destroy the protected habitat with attendant decline in its biodiversity resources.

\section{Procurement of Medicinal products}

Most of the remedies for the treatment of some common ailments that occur in rural settings can be found in the forests as plant materials (Farnsworth et al., 1985). The knowledge of such remedies is very basic, and key to the survival of many local communities that inhabit areas around protected areas, especially in the rural areas where modern medical facilities may not be located near the community. Medicinal products obtained from the protected areas therefore act as a first aid box or a pharmaceutical store from which herbal and animal remedies are procured by traditional healers and their apprentices for the treatment of patients that are down with ailments from the local population. When not harvested properly, the habitat is damaged, (Shanley \& Luz, 2003), leading to decline or loss of low density plant species (Cunningham, 1993). Sometimes the level of poverty among the local communities is so high that one can not contemplate the prospect of getting treatment without these herbs, given that most locals can not afford the medical bills in orthodox medical facilities even if they were provided in the area. It is therefore inexorable that the practice of unsustainable harvesting of herbal materials in protected areas will not abate. It rather continues to impact negatively on the habitat of the protected area. The temptation also to earn income as a result of the booming traditional medicine market has also encouraged the illegal exploitation of exotic plant species (Shanley \& Luz, 2003) and the poaching of wildlife of medicinal importance in many countries. However, this factor is rather extrinsic, as it does not relate to the basic need of the locals.

\section{Killing wildlife as bush meat: a source of protein supplementation}

This is one of the major reasons why game animals are poached by the local inhabitants of protected areas. Seeing that they are surrounded by hordes of different species of animals that are easily within reach, many local inhabitants feel that these animals can easily be slaughtered for their daily meals like domesticated animals as a source of protein supplementation. For instance, in the Banyang-Mbo Wildlife Sanctuary, an area of lowland tropical rainforest in southwestern Cameroon, bush meat was significantly cheaper than the alternative sources of protein available in the nearest town (Wilcox \& Nambu, 2007). In many protected areas, partnerships formed with communities living adjacent to protected areas has not resulted to sustainable use of wildlife resources as the local people continue to kill wildlife both home consumption, and income generation (Rose 1998, Algotsson, 2006). The latter is however not a necessary need which the locals can not do without as there may be other avenues for income generation available to these people.

\section{Killing wildlife by farmers to curb raids on agricultural crops}

The destruction of agricultural crops by wildlife has been a major problem that farmers near protected areas have to contend with from one cropping season to another (Gillingham \& Lee, 2003). These raids inflict heavy losses on farm produce with the cost borne by the local farmers. Although it may not be voiced out, many farmers around the protected areas silently kill the animals that raid their crops in order to protect these crops from further attacks by the animals and minimize the loss of farm produce (Ferraro, 2002). Heavy losses of farm produce may lead to famine and decreased food security (Ogra, 2008), since most farmers in these areas produce just enough to feed their families. The destruction of the dry foliage in the dry season which is useful as food for some large herbivorous animals through bush burning lead to the hunting down of some entrapped animals which is very common practise among African communities. It also destroys the necessary cover needed by the animals for their protection from predators, and inadvertently encourages wildlife species to migrate and look for cover from predators, as well as foliage already charred by burning. Wandering herd or flock of wildlife in search of both needs may encounter and destroy agricultural crops (Chiyo et al., 2005). In turn these animals would be hunted and killed by farmers of such crops depleting the wildlife population and defeating the very essence of wildlife conservation.

Extrinsic Factors That Promote Over Exploitation of Protected Areas by Local Inhabitants: Extrinsic factors are external pressures or secondary forces that drive poaching of game and other resources in the protected areas. Such forces are not necessarily compelling needs of the immediate communities surrounding the protected areas. However, insiders within the local 
community may collaborate with some external agents to exploit the resources in the protected areas in an unsustainable way. The following factors play a part in this regard.

\section{Population increase}

Population increase leading to settlement expansion has encourage invasion of protected areas and the destruction of habitat suitable for thriving of animal and plant species thus decreasing the extant biodiversity in the protected environment. Human population increase has brought about the need for expansion of human settlements and other infrastructural developments such as the opening up of access roads. The Masai Mara National Reserve Kenya is a classical example population increase in the number of tourists to the park has led to increased development in infrastructural facilities (Mundia \& Murayama, 2009) to accommodate visitors and promote tourism. However the development has increased habitat fragmentation, destroying carving ground for wildlife species, and altering migration patterns (Mundia \& Murayama, 2009). These human population increase and development patterns have contributed in no small measure to atrophy the size of some protected areas (Wittemyer et al., 2008).

\section{International trade in endangered wildlife and plants species}

The lure for income generation through illegal trading in wildlife products has encouraged the hunting and killing of wildlife for their animal products for trade and income generation (Algotsson, 2006), despite international outcry and ban in such trade. There is evidence that this trade has encouraged the extra extirpation of endangered species such as the elephants for the sales of ivory, at the local level in protected areas (Bulte et al., 2007), bear, reptiles and primates (Rose, 1998). While the total removal of natural habitat is clearly a major threat to the survival of many wildlife species as well as their decline, an analysis of survey data suggests that human predation tends to have a greater negative impact on wildlife populations than does selective logging or subsistence agriculture (Rose, 1998). The added incentive as a result of income generated through the sales of wildlife products (Rose, 1998, Bulte et al., 2007), and plants products (Shanley \& Luz, 2003) has continued to elicit extra killing of wildlife and unsustainable harvesting of plants products in protected areas leading to their decline.

\section{Deforestation}

In rural tropical settings, the value of tropical forests to local residents as sources of food, construction materials, remedies, and myriad other natural products can exceed the value produced by logging or felling the forests trees (Balick \& Mendelsohn, 1992).Tree harvesting adversely affects the population and variety of plant and animal species in the forest (Laurance, 1999). The removal of forest cover during logging has in some instances resulted in the scarcity or out-right extinction of many important plant and animal species. Some wild animals have also been observed to migrate from areas where tree cover was removed to undisturbed vegetations. Some plant and animal genetic resources that could be used in producing new pharmaceuticals or traditional medicine are lost as a result of the destruction of forest cover (Fuwape, 2001). Logging has also provided access to a wide of range of previously inaccessible forest habitat, increasing the killing of wildlife by hunters in these protected areas as well as the logging companies (Laurance, 1999). It has been noted that the removal wildlife like elephants and tapirs which help in forest regeneration through seed dispersal invariably harms the forest habitat, having a negative feed back on the ecosystem. Although communities in protected areas actively participate in deforestation, they are fewer actors compared to multinational companies that engage in logging for timbre production or commercial plantations with tacit government approval.

Proposed Solutions to Curb Anti Conservation Activities by Local People in Protected Areas: Most partnerships that are formed between managers of protected areas and the locals to stimulate their interest in biodiversity conservation, and help to participate in the scheme only think of shared economic benefits derived through ecotourism, and the controlled harvesting of products as being sufficient to make them long term partners (Mbaiwa, 2005). No attempt is often made to understand the basic needs of the locals that are intricately tied to the land and the resources therein that are important to the daily survival of these people. Understanding these basic needs, the social cultural and traditional needs and the land use policy of the local community will enable park managers to be able to decide how best the locals will contribute toward conservation of the protected area. Partnerships will be formed, but if the daily basic needs of the local people are not met, when these can be often obtain from the conserved habitat, then, these partnerships will be unilaterally abandoned (Wessels et al., 2003). Studies are needed to determine what is needed by individual communities as the needs may vary. One way to discourage anti conservation practices by the local is to first reduce the level of poverty among these people. Apart from gains derived from ecotourism, this can be achieved by promoting alternative economic activities that rely on properly preserved habitat such as bee keeping, and aquaculture (Garcia-Frapolli et al., 2007), bearing in mind the local resources available to the area. The training of locals who may be recruited to work in the protected areas in order to build and strengthen their capacity by sending them on training workshops from time to time will stimulate their interest in prolonged partnership for conservation. If it is perceived that the basic needs of the locals reside within the protected area, the locals should be encouraged to use their traditional methods of conservation and sustainable utilization of the perceived resources rather than banning them, or park managers dictating how the resources should be conserved. In this way these people would appreciate their inputs, and feel a sense of belonging in the biodiversity conservation project.

\section{CONCLUSION}

This paper has linked poverty and basic needs of local communities in protected areas as the driving forces that compel these people to over exploit natural resources in protected areas to the detriment of biodiversity conservation. It is believed that alleviating poverty among the locals as well as identifying and providing for needs that are basic to the daily survival of the local people in protected areas is the key to promoting sustainable utilization of natural resources resident in protected areas among the locals in line with biodiversity conservation goals.

\section{REFERENCES}

Algotsson, E. (2006). Wildlife conservation through people-centred approaches to natural resource management programmes and the control of wildlife exploitation. Local Environment, 11(1): 79-93. 
Ancrenaz, M.; Dabek, L. \& O'Neil, S. (2007). The costs of exclusion: Recognizing a role for local communities in biodiversity conservation. PLoS Biology, 5 (11): e289. doi:10.1371/journal.pbio. 0050289

Balick, M. J. \& Mendelsohn, R. (1992). Assessing the economic value of traditional medicines from tropical rain forests. Conservation Biology, 6: 128-130.

Berkes, F. (2004). Rethinking community-based conservation. Conservation Biology, 18 (3): 621-630.

Borrini-Feyerabend, G.; Kothari, A. \& Oviedo, G. (2004). Indigenous and local communities and protected areas towards equity and enhanced conservation. World commission in protected areas, Series number 11. Gland (Switzerland): IUCN Publications.

Bulte, E. H.; Damania, R. \& van Kooten, G. C. (2007). The effects of one off sales on elephant mortality. Journal of Wildlife Management, 71 (2): 613-618.

Carey, C.; Dudley, N. \& Stolton, S. (2000). Squandering paradise? The importance and vulnability of the world's protected areas. WWF-World Wide Fund for Nature (formerly world Wide Fund) International, Gland, Switzerland.

Chambers, R. (1986). Sustainable livelihoods. Institute of development Studies, University of Sussex, Sussex.

Chiyo, P. I.; Cochrane, E. P.; Naughton, L. \& Basuta, G. I. (2005). Temporal patterns of crop raiding elephants: a response to changes in forage quality or crop availability. African Journal of Ecology, 43: 48.

Cunningham, A. B. (1993). African medicinal plants setting priorities at the interface between conservation and primary health care. Paris: UNESCO. People and plants Working Paper 1.

Dikobe, L. (1995). People and parks; do they mix? In The present status of wildlife and its future in Botswana, Kalahari conservation Society, Gabarone, :91-94.

Eken, G.; Benun, I.; Brooks, T.M.; Darwall, W.; Fishpoll, I.D.C.; Foster, M.; Knox, D.; Langammer, P.; Matiku, P.; Radford, E.; Salaman, P.; Scherest, W.; Smith, M. I.; Spector, S. \& Tardoff, A. (2004). Key biodiversity areas as site conservation targets. Bioscience, 54: 1110-1118.

Ferraro, P. J. (2002). The local cost of establishing protected areas in low income nations. Ranomafana National Park Madagascar. Ecological Economics, 43 (2-3): 261-275.

Fuwape, J. A. (2001). The impacts of forest industries and wood utilization on the environment. Journal of Tropical Forest Research, 17 (2): 78-90.

Garcia-Frapolli, E.; Ramos-Fernandez, G.; Galicia, E. \& Serrano, A. (2009). The complex reality of biodiversity conservation through natural protected area policy: three cases from the Yucatan peninsula, Mexico, Land Use Policy, 26: 715-722.
Gillingham, S. \& Lee, P. C. (2003). People and protected areas: a study of local perceptions of wildlife, crop - damage, conflict in an area bordering the Selous Game Reserve Tanzania. Oryx, 37: 310325.

Harris, F.M. A.; \& Mohammed, S. (2003) . Relying on Nature: Wild Foods in Northern Nigeria. AMBIO: A Journal of the Human Environment , 32 (1): 24-29.

Hogkins, M.; Stolton, S.; Leverington, F.; Dudley, N. \& Courrau, J. (2006). Evaluating effectiveness: a framework for assessing management effectiveness of protected areas, $2^{\text {nd }}$ ed. Gland (Switzerland): IUCN Publications.

Kiwasila, H. L. \& Homewood, K. M. (1999). Natural resource use by reserve-adjacent farming communities. In: Mkomazi. The Ecology, Biodiversity and Conservation of a Tanzanian Savanna. Coe, M., McWilliam, N., Stone, G. and Packer, M. (eds). RGS / IBG, London.

Laurance, W. F. (1999). Reflections on the tropical deforestation crises. Biological Conservation, 91: 109-117.

Mbaiwa, J. E. (2005). Wildlife resource utilization at Moremi Game Reserve and Khwai community area in the Okavango Delta Botswana. Journal Environmental Management, 77: 144-156.

Mundia, C. N. \& Murayama, Y. (2009). Analysis of land use/cover changes and animal population dynamics in a wildlife sanctuary in East Africa. Remote Sensing, 1: 952-970.

Ogle, B. (1996). People's dependency on forests for food security. Some lessons learnt from a programme of case studies. In: Current Issues in Non-timber Forest Products Research. Perez, M.R. and Arnold, J.E.M. (eds). Centre for International Forest Research, Bogor.

Ogra, M. V. (2008). Human-wildlife conflict and gender in protected area borderlands: A case study of costs, perceptions, and vulnerabilities from Uttarakhand (Uttaranchal), India. Geoforum, 39 (3): 1408-1442.

O'Riordan, T. (2002). Protecting beyond the protected. In O'Riordan, T., Stoll-Kleemann, S. (eds.), Biodiversity, Sustainability and Human Communities, Protecting beyond the Protected. Cambrige University Press, Cambridge, Cambridge.

Ribot, J. C. (1993). Forest policy and charcoal production in senegal. Energy Policy, 21 (5): 559-585.

Rodrigues, A. S. I.; Akcakaya, H. R.; Andelman, S. J.; Bakarr, M. I., Boitani.; I., Brooks, T. M.; Chanson, J. S.; Fishpool, I. D. C.; Da Fonseca, G. A. B.; Gaston, K. J.; Hoffmann, M.; Marquet, P. A.; Pilgrim, J. D.; Pressy, R. I.; Schipper, J.; Sechrest, W.; Stuart, S. N.; Underhill, I. C.; Waller, R. W.; Watts, M. E. J. \& Yan, X. (2004). Global gap analysis: priority regions for expanding the global protected-area network. Bioscience, 54:1092-1100.

Rose, A. L. (1998). Growing commerce in bush meat destroys great apes and threatens humanity. African Primates, 3: 6-10. 
Sekhar, N.G. (2003). Local peoples attitude towards conservation and wildlife tourism around Sarika Tiger Reserve, India. Journal of Environmental Management, 69: 339-347.

Shanley, P. \& Luz, L. (2003). The impacts of forest degradation on medicinal plant use and implications for health care in Eastern Amazonia. Bioscience, 53 (6): 573-584.

Tabuti, J. R. S.; Dhillion S. S. \& Lye, K. A. (2003). Firewood use in Bulamogi County, Uganda: species selection, harvesting and consumption patterns. Biomass and Bioenergy, 25 (6):581-596.

Wessels, K. J.; Rayers, B.; van Jaarsveld, A. S. \& Rutherford, M. C. (2003). Identification of potential conflict areas between transformation and biodiversity conservation in north-eastern South Africa. Agriculture ecosystem and Environment, 95 (1): 157-178.

Wilcox, A. S. \& Nambu, D. M. (2007). Wildlife hunting practices and bushmeat dynamics of the Banyangi and Mbo people of Southwestern Cameroon . Biological Conservation, 134 (2): 251261.
Wilshusen, P. R.; Brechin, S. R.; Fortwangler, C. L. \& West, P. C. (2002). Reinventing a square wheel: critique of a resurgent "protection paradigm" in international biodiversity conservation. Society and Natural Resources, 15: 17-40.

Wittemyer, G.; Elsen, P.; Bean, W. T.; Burton, A. C. O. \& Brashares, J. S. (2008). Accelerated Human Population Growth at Protected Area Edges. Science, 321 (5885): 123-126.

Wood, A. (1993). Natural resources conflicts in South West Ethiopia. In Hurskanien, A., Salih, M. (eds.), Social Science and Conflict Analysis. Nordiska Afrikaistitutet, Uppsala. 